\title{
Developing Cultural Awareness: The Text-Driven Approach as Evidence of a Good Language Teaching Practice
}

\author{
Laura Cardona, Carlos Rico, Susan Sarmiento \\ Communication and Language Department, Pontificia Universidad Javeriana, Bogotá, Colombia \\ Email: cardona.laura@javeriana.edu.co, crico@javeriana.edu.co, susksar1201@yahoo.com
}

Received 12 June 2015; accepted 18 July 2015; published 21 July 2015

Copyright (C) 2015 by authors and Scientific Research Publishing Inc.

This work is licensed under the Creative Commons Attribution International License (CC BY). http://creativecommons.org/licenses/by/4.0/

(c) ()

\section{Abstract}

The present article reports a descriptive and explanatory case study, whose objective was to identify and describe to what extend students develop cultural awareness through activities designed under the principles of the Text-Driven Approach (TDA). This approach, presented by Brian Tomlinson, answers the question of how a second language can be learned or acquired in the most effective way in the classroom, and also aims to design interesting materials for students which lead them to think, reflect, and communicate. The research deals with developing cultural awareness in Elementary English students in the Modern Languages Degree at Pontificia Universidad Javeriana. Basically, the research development comprised 3 stages. The first one consisted of the identification of the problem, which was intended to figure out if students develop cultural awareness in their English classes; the second stage was intended to design a set of activities following the TDA principles. Said design became the core of the pedagogical intervention to give answers to the problem found. The third stage was featured by the implementation of the activities in two different classrooms for a period of three months. During such implementation of the activities, data were collected by using 3 important instruments: the observation sheets, which were helpful in order to gather information about observable students' behaviors (what students do). The second instrument was a questionnaire, in which students had the opportunity to express what they thought and learned during the implementation of the activities (what students say they do) and finally, we count on artifacts from students (what students really do), regarding the activities designed in order to develop cultural awareness; such artifacts were found by means of the teacher's guide, the document in which the activities were presented. Therefore, the same phenomenon was observed from 3 different perspectives obtaining a triangulation, a technique, which was considered the most appropriate to do the analysis of the data. The information collected led researchers to 4 important categories through which answers were given to the research question: knowledge (savoir), socio-cultural competence (savoir fare), attitude (savoir être), understanding "the other". Such categories allowed researchers to classify the information gathered and obtain the 
preliminary findings, which showed that the activities designed definitely developed cultural awareness to some extend in Elementary English students.

\title{
Keywords
}

\author{
Cultural Awareness, Text-Driven Approach, Attitude, Knowledge, Socio-Cultural Competence, \\ Understanding "the Other"
}

\section{Introduction}

Cultural awareness becomes central when we have to interact with people from other cultures. People see, interpret and evaluate things in different ways and something that is considered an appropriate behavior in one culture is frequently inappropriate in another one. It is clear that misunderstandings arise when one uses his/her own meanings to make sense of the meanings of the others (Quappe \& Cantatore, 2005). Misinterpretations occur primarily when we lack awareness of our own behavioral rules and project them on others. In absence of better knowledge, we tend to make assumptions, instead of finding out what a behavior means to the person involved.

This paper reports a research that was carried out in an elementary English language classroom at a university context in Bogotá-Colombia where students are to study teaching languages. The aim of this research was to describe how English students develop cultural awareness by means of the implementation of a set of activities designed following the principles of the Text-Driven Approach presented by Tomlinson (2000). Such approach focuses on answering the question of how a language can be learnt or acquired in the most effective way, and also proposes a methodological route for the design of interesting materials.

\section{Problem}

Three important steps were followed in order to identify the problem. The first step was to get students to answer a questionnaire and respond to an informal interview in order to obtain information about the activities developed in their English class, their conceptions about learning a second language and the course book used (see Annex 1). The second step consisted of reviewing the English syllabus of the program, checking if the aspects of culture or cultural awareness were to be developed during the classes. The third step was based specifically on an evaluation of the course book used in Elementary English courses at the University.

In general, the results from both the questionnaires and the interviews demonstrated that for these students it is very important to study grammar and do structural exercises in order to learn the language. Students at this early level do not consider culture as one of the main elements of the language learning and teaching process. They believe that culture is only about knowing and receiving foreign information. They do not know that developing cultural awareness is as important and necessary as developing linguistic and communicative skills in this process.

The program is mostly based on the Communicative Approach and the classes are mostly focused on developing communicative functions that allow students to participate successfully in a communicative context. The problem is that these types of activities are based on developing the four skills: writing, reading, listening and speaking, and on getting students to communicate in certain situations, but they do not offer many chances to reflect on their own and the target culture, or opportunities to develop other competences.

Besides the type of activities, another reason for students not to develop cultural awareness is the course book and the materials used in class. Some of these materials are created or designed without taking into account the needs or the context of the population for whom they are used. Major publishing companies that manage the global market create materials that are based on purely grammatical aspects and exercises ignoring or emphasizing less other aspects that are equally essential in the language learning process such as the development of cultural awareness that leads students to reflect on and make a comparison of their own and other cultures. When these books refer to culture, they usually do it in order to give historical or cultural information or showing famous places and symbols in the world (big C), but they do not exceed social visible artifacts.

Keeping in mind all of the above, we can say that we are greatly in need of materials that respond to the needs of our population and context, since the materials currently used for learning languages are paradigms of capi- 
talist and imperialist markets with different conceptions of what a language is. They do not facilitate the development of important aspects or competences in students which are needed as part of their language learning process.

\section{Rationale}

We believe that a specifically designed set of activities can develop students' cultural awareness following the principles of the Text-Driven Approach, since both aspects involve students' reflections, perceptions, expectations and points of view of the target and the own culture. We also believe it is relevant to create activities that develop cultural awareness in the educational process of the degree in Modern Languages at the University, in order to foster in future teachers an intercultural critical stance, based not only on judgments towards the language worked but rather on an analysis and deep understanding of their own culture.

Our work makes a theoretical contribution regarding the use of the methodological route given by the Text Driven Approach. This approach is based on the learner and aims at developing the learners' capacities and dimensions (thinking, reflecting and communicating). Additionally, this approach has not been developed in the context where students are immersed in the language acquisition. Finally, this approach empowers students to think and reflect on certain cultural aspects, making fluent, effective and appropriate use of the target language.

\section{Theoretical Support}

The main theoretical constructs that supported the current research were: the importance of understanding the multicultural context, the relationship between culture and language, the language policies, what an intercultural learning and intercultural speaker mean, the definition of cultural awareness, the different dimensions of knowledge (saviors according to Byram’s theory, 1997) and finally the importance of understanding “the other”.

\subsection{Our Multicultural Context Language Learning and Culture}

According to Byram (2003), modern societies are multifaceted and the responsibility of education is to change as a consequence of societal change. What may have beforehand been conceived as simple realities-notably the idea of the nation-state with one language and culture shared by all its citizens — are no longer true, and in fact have rarely been so. The role of formal education, in the life of individuals and in the evolution of societies - and of language education as a major element of schooling — has changed and will probably continue to do so. Multilingualism in societies and the plurilingualism of individuals is now usual and education for plurilingualism is necessary.

It is to mention that our multicultural context underlies our pedagogical practices. On Izadpanah (2011) claims that culture influences language teaching in two important ways: linguistically and pedagogically. Linguistically, culture is significant in the linguistic dimension of the language itself, affecting the semantic, pragmatic, and discourse levels of the language. Pedagogically, it influences the choice of language materials because cultural content of the language materials and the cultural basis of the teaching methodology are to be taken into consideration while deciding upon the language materials (Izadpanah, 2011). Definitely, language cannot be separated of culture thus learning any language implies a systematic reflection about the culture which surrounds such a language.

\subsection{Language Learning and Culture}

Each country or nation has its own unique culture which is nurtured and shared by its members within the community and manifested in terms of linguistic, paralinguistic and non-verbal forms. Culture has become an increasingly and important component of language teaching in the last three decades, but the controversy concerning language acquisition in conjunction with culture is one that is still very present today. Linguistics has recognized that the forms and uses of a given language reflect the cultural values of the society in which the language is spoken.

Although culture was not integrated in language teaching programs in the world until the 1950's, the relationship of language and culture related to language teaching has long been recognized by many scholars, educators and teachers. Culture has been included in practical language teaching in different ways and since the 1950's and 1960's, cultural aims have appeared in many official language teaching objectives in different parts 
of the world. Therefore, it was taken as a more serious aspect to deal with. The works in language teaching theory during the 1950s, 1960s and 1970s have shown the importance of the teaching of culture while teaching the language, since we are teaching something meaningless if we teach the language without teaching culture. In the 1980s and the 1990s the issue was tackled with much more importance by experts in the area such as Byram (1989) and Kramsch (1987).

\subsection{Language Policies}

Now with respect to language policies, we have to mention that we are living in a multilingual and a multicultural reality. It is a context in which there are a huge number of languages; many of them are spoken next to one another. It is understood that all the languages have the right of existence and maintenance. Alongside of this enormous linguistic variety we find enormous cultural diversity on our immediate context. It is well known that linguistic plurality and cultural diversity are at the basis of our modern societies, as mentioned in the Common European Framework of Reference.

The Common European Framework of reference for languages (CEFR, 2001) which is the guideline used to describe achievements of learners of foreign languages across Europe and increasingly in other countries, like Colombia, demands not only to develop research and acquisition of a foreign language, but also the development of an intercultural competence in order to satisfy the needs of a multilingual and multicultural Europe. "It is a fundamental truth that cultures define themselves through languages” (Kirkeby, 2008).

The aforementioned document states a clear objective in terms of guarantee a deep reflection about the importance of teaching languages in the frame of cultural diversity. In this regard, the CEFR (2001) determines as an objective "to achieve greater unity in the development, classifications and assessment of languages, so that the people involved with the process of language learning have greater global mobility, more effective international communication combined with the respect for the identity and cultural diversity” (CEFR, 2001).

\subsection{Intercultural Learning}

Intercultural learning, on a more accurate level, refers to an individual process of acquiring knowledge, attitudes or behaviour that is related to interaction of different cultures. Intercultural learning aids to make clear how people with different backgrounds can live together harmoniously. It delineates both the competences needed as well as the process to be used to achieve that aim (Lafraya, 2011). In that sense, intercultural learning is not just about learning from books. It concerns learning about oneself to start with, about others and their differences, and finally, about what is cultural in each individual.

Encouraging cultural and intercultural awareness engages discovering and understanding one's own culturally conditioned performance and believe, in addition to the models of others. Therefore, the procedure to become culturally aware involves not only recognizing the similarities and differences in other cultures, but also perceiving the backgrounds of the native culture or, as Hall (quoted in Fenwick, Nesbit \& Spencer, 2006) refers, our own hidden culture.

An important distinction between intercultural learning and other types of second language learning such as language socialization is that once language learners develop a cultural understanding of the second language group, they may or may not wish to adopt the practices or beliefs of the new culture (Corbett, 2003). In other words, there is recognition of desired degrees of acculturation into a language, which puts language learners in a position of making informed choices about language learning and cultural behaviour, preventing the risk of hegemonic structure entering into second language education.

\subsection{Intercultural Speaker}

The intercultural speaker has "a willingness to relativize one's own values, beliefs and behaviours, not to assume that they are the only possible and naturally correct ones, and to be able to see how they might look from the perspective of an outsider who has a different set of values, beliefs and behaviours” (Byram, Nichols, \& Stevens, 2001).

Here one should remember that the concept of intercultural speaker is based on the idea of cultures being well-defined, cohesive units that clearly differ from each other and that even so are equipped with certain shared structural features. Precisely for that reason, "it is possible to compare cultures and mediate between them" 
(Risager quoted in Byram, 1998). In other words, one is using a relatively traditional understanding of what culture is. The point of departure is not a modern concept of culture which understands cultures as complex entities that are interwoven in various ways, e.g. virtually via mass media and purely physically via people (and material products), who, in a concrete sense, move between various contexts as a result of international cooperation, migration, tourism, etc. "The intercultural speaker is understood, then, as a person who mediates between relatively well-defined linguistic and cultural entities and between people whose ways of thinking and acting are strongly influenced by these linguistic and cultural entities” (Jæger, 2001).

\subsection{Cultural Awareness Knowledge (Savoir)}

Cultural awareness, as the most relevant term for this paper, is according to Tomalin and Stempleski "sensitivity to the impact of culturally-induced behaviour on language use and communication” (Tomalin \& Stempleski, 1993 in Álvarez \& Bonilla, 2009). Cross-cultural, "covers beliefs, values, attitudes and feelings conveyed not only by language but by paralinguistic features such as dress, gestures, facial expressions, stance and movement”. Developing sensitivity and understanding, another ethnic group includes internal changes in attitudes and values. Qualities such as openness and flexibility towards other people also show an important role in developing cultural awareness.

At the same time, we think that cultural awareness becomes central when we have to share with people from other cultures. People deduce and evaluate things in different ways. What is considered an appropriate behaviour in one culture is frequently inappropriate in another one. Becoming aware of our cultural natural process is a difficult mission bearing in mind that culture is not conscious to us. "Given the fact that when we were born we learn to see and do things at an unaware stage. Our experiences, our values and our cultural background lead us to see and do things in a certain way. Sometimes we have to step outside of our cultural boundaries in order to realize the impact that our culture has on our behaviour” (Quappe \& Cantatore, 2005).

At the same time, skills and attitudes together with knowledge make competence. This competence is called sociocultural competence. It enables a language learner "to develop an enriched, more complex personality and an enhanced capacity for further language learning and greater openness to new cultural experiences” (CEFR, 2001).

\subsection{Knowledge (Savoir)}

Apart from what we have already mentioned, it is necessary to affirm that when we are in the position to communicate with someone else that portrays different socio-cultural background, we need to display all our knowledge. This knowledge is the result of our way of being in the world and it is connected to what Bourdieu called habitus. Bourdieu (1994) talks about two individual processes: “the learner's habitus” and "cultural capital” which vary from one learner to the other. "Habitus" is a "set of dispositions which incline agents to act and react in certain ways". The dispositions reflect social conditions of the student's background and differ from one social class to another or from one nationality to another. According to Bourdieu the student's habitus will generate attitudes, perceptions and practices which are not consciously coordinated and will thus be a determining factor in acquiring knowledge. "Cultural capital" is a concept used by Bourdieu to describe the knowledge, skills and other cultural acquisitions which the individual possesses. This is dependent on social background and will vary from one learner to another.

\subsection{Social-Cultural (Savoir-Faire)}

Usually socio-cultural competence is seen as a set of skills which the foreign language learner has to be acquainted with in order to cope in the target culture. It has been one of the two main components in the teaching of culture, increasing greatly in importance with the development of a communicative approach to language teaching.

Through dialogues and other speech-patterns course books have given the foreign language learner models for what to say and how to act in various hypothetical social situations in the target culture. Sample dialogues have often been followed by role-play and information gap tasks. Such tasks can be important for developing socio-cultural skills, but they tend to become ritualistic and meaningless to the learner. Also one can question the belief that learners will automatically be able to transfer skills developed in the classroom to the real situation. Because neither skills nor knowledge can be transferred automatically, socio-cultural competence has to be de- 
veloped through a more comprehensive understanding of interaction with the foreign culture.

\subsection{Attitude (Savoir Être)}

Attitudes refer to the idea of developing a better understanding and tolerance towards others. Interaction is a process in which participants have to constantly change and readjust their points of view. One enters into the process with a conscious or subconscious attitude of wanting to influence or persuade "the other". This is even more the case when "the other" is a foreign culture expressed in a foreign language. Being in a proper dialogue can be a painful process. It is painful because one tends to defend one's own position and resist a change of attitude and opinion. In a foreign language learning context one should not be surprised when tolerance and understanding are not immediate results of learning a foreign language and encountering a foreign culture.

\subsection{Understanding "the Other"}

It is a fallacy to believe that we can reach a point where we will be able to understand "the other" completely. We do not even understand ourselves and our own culture to such an extent. But in the foreign language classroom it is important to open up for a variety of encounters with the foreign culture and provide possibilities for reflecting individually and in a social context upon these encounters. This also means reflecting upon the multiplicity of meaning that exists in any culture and which can be made potentially available through various types of texts.

The foreign culture provides the mirror in which we can see ourselves reflected; it provides an outside to our inside. While learning a foreign language, the learner will bring his own culture into the communication process with the foreign culture, whether it is in reading a foreign text or in speaking to a representative of that particular language community.

\subsection{Methodologies in Second Language Teaching}

Up to here, it is clear to observe the importance of incorporating cultural and intercultural awareness in our language classrooms. The biggest question for teachers is how to do it. Teachers can explore different methodologies to achieve such a goal. One of these methodologies is the Text Driven Approach. Changes and shifts in language teaching have been present throughout the history of this discipline. The need for communication among people of different cultures and languages has been triggered by travelling and globalization and puts pressure on people to learn languages more quickly and efficiently.

\subsection{Text-Driven Approach}

This approach created by Tomlinson (2000), answers the question of how a language can be learned or acquired in the most effective way in the classroom. It is ideal for the development of course books and supplementary material. The strength of this approach is as Tomlinson (2000) has expressed, it helps writers and speakers to produce materials and consistent principles, quickly, effectively and to articulate and develop their own theories about learning and teaching languages at once. Students are encouraged to respond holistically, affective and multi-dimensionally to a text before being helped to think more. The idea is to help them to discover their own answers.

Basically the Text-Driven Approach is a methodology in which a potentially engaging text (a poem, song, story, joke, article, film or TV programme) is used as a starting point for presenting the learners with a series of achievable challenges. The aim is to stimulate multi-dimensional representation of the text and to use this to help the learner to develop skills, awareness, confidence and self-esteem.

\section{Method}

After identifying the problem, we continued with the second stage whose purpose was to design activities following the principles of the TDA. A total of three different activities were designed and applied in two different classrooms for a period of three months. The topics of the designed activities were directly related to the topics covered in the program.

The principles of the TDA are divided into two parts: the first one consists of the text collection and text selection principles. The other principles of the TDA are experiencing the text again, readiness activities, expe- 
riential activities, intake response activities, development activities and input response activities which also includes interpretation tasks and awareness task, constituted the second part.

For the text collection principle we gathered a series of reading and listening texts extracted mainly from the internet, books and podcasts. We collected close to 40 texts about different topics, like food, places, cities, movies, professions, countries, music, hobbies, chores, school, etc. After collecting a substantial amount of texts we continued with the texts selection principle. We selected the texts according to the level of proficiency of the students, the topic to be studied and also we looked for texts that students could have fun with and learn from. Activity 1 was related to "cities", Activity 2 to "jobs and places of work" and Activity 3 is related to "leisure time".

Before starting to create each one of the activities, we went through the experiencing the text again principle. We read and listened to the text once again, tried to make reflections on our own experiences of the text and re-engage with the text. We also discussed, shared our thoughts and agreed on the best way to guide students to experience a similar engagement through the activities.

After experiencing the text, we started creating the activities by designing the readiness activities. Since the purpose of this principle is to activate students' minds and make them think; in Activity 1 that was related to cities, students had to look at three images of three buildings: the Burj Al Arab, in Dubai, the Empire State Building in NY and the Colpatria tower in Bogota and students had to reflect and decide what image they like the most as well as the importance they believe these buildings have for their countries. After that, some students had the chance to share their answers with the class. For activity 2 the text was a song and for activity 3 the text was a video.

The following step was to create experiential activities, by using the text selected from the collection text principle. For Activity 1 the text was a reading about "the British Museum". It was quite interesting since it talked about its history and great possessions. For this activity there was a box with some words that were missing in the reading, so students needed to complete the text with them.

We then continued with the input response activity which consisted of two parts: interpretation tasks and awareness activities. In Activity 1 students needed to be in groups and the interpretation activity was about answering questions regarding the "British Museum" reading. These questions were multiple choice, so each group had the chance to correctly answer one question. If they did, then the teacher asked follow-up questions to fully assess the comprehension of the text.

The following step was the creation of the Awareness tasks which were planned for students to become aware of their own values and how these influence their views of other people's values. Keeping this purpose in mind, in Activity 1, the Awareness task was about answering the following questions: What aspects do you consider important when visiting a place for the first time? What would you say to or advise a person who is visiting a place in your country for the first time? Compare your answer with your partner and agree on the advice.

After the awareness tasks, we concentrated on creating the Intake Response activities in order to invite students to reflect on the representations they already had in their minds. For Activity 1, in groups, students had to fill in a chart establishing differences and similarities between the British museum and any other museum they have been to before.

The last principle we followed is called Development Activities. In order to provide opportunities for meaningful language production based on learner's representations of the text (Rico Troncoso, 2011) in Activity 1, we created a task which was to recreate a scene in a museum in small groups, where one of the participants is the guide and the rest are tourist from different parts of the world.

The third and last stage of the present research consisted of the application of the designed activities. Three instruments were used in order to collect the data: observation sheets, artifacts and questionnaires. The observation sheets were helpful in order to gather information about students' observable behaviors (what students do). In the questionnaire, students had the opportunity to express what they thought and learned during the implementation of the activities (what students say they do), and finally, we counted on artifacts from students (what students really do). Therefore, the same phenomenon was observed from three different perspectives, allowing the researchers to make a triangulation, a technique which was considered the most appropriate to do the analysis of the data.

After having collected all the information by means of the three instruments, the researchers continued with the analysis of the data: we transcribed, listed and contrasted one by one, the answers to the questionnaires, the information collected from the observation sheets and also everything students wrote on the student's guide. 
After having collected all the information by means of the three instruments, the researchers continued with the analysis of the data: we transcribed, listed and contrasted one by one, the answers to the questionnaires, the information collected from the observation sheets and also everything students wrote on the student's guide.

Regarding the analysis, we proceeded to create huge posters with long lists of pieces of paper, which we started moving and grouping according to what they said. We ended up having five categories under which the data could be classified, and at that point, we realized we could definitely use the same categories defined in the theoretical framework to show the findings of our research. Such categories include: Knowledge (savoir), Socio-cultural Competence (savoir faire), Attitude and Understanding "the other". The fifth category which we called 'Self-reflection' was not defined in the theoretical framework. We had not considered it at the moment. This new category emerged when doing the analysis. Moreover, we also realized that every stage of the TDA was directly linked to such categories in order to observe the development of cultural awareness. But before, it is important to mention the population.

\section{Population}

Taking into account the research question, we decided to work with, Elementary English students who are starting the Program of Modern Languages at the University. We performed a total of 5 pedagogical interventions in 2 different groups. The first group was compound by 13 students: 9 women and 4 men, between 17 and 19 years old. 16 students were part of the second group: 12 women and 4 men, within the same age ranges.

In the same way, the total amount of students who participated in this research project was 29. After being informed of the purpose of this research they decided to participate voluntary. They signed a consent form in which they gave the authorization to use the data gathered for publication, protecting their anonymity. They were reassured that the researchers were the only ones who had access to the information. Additionally, they were told that they could withdraw at any time without giving any reason.

As additional information in regards to the participants, we can say that students' proficiency level in English was between A1 to A2 according to the CEFR (2001). They all share a similar situation and perceptions, since they are Colombian with variations in the region. We had the opportunity to work with students from Medellin, Santa Marta, Cartagena and Ibague.

It is necessary to mention that even though the activities were implemented in two different groups, we did not mean to make comparisons between them or between students, neither to make experiments. We just decided to work with different groups to somehow validate the effectiveness of the activities rather than compare or judge.

\section{Results}

\subsection{Knowledge (Savoir)}

We discovered this category was linked to the stage of the TDA called "Readiness Activity". The activities had students talk about their perceptions and their opinions, articulate their views, and think of connections. In order to achieve such purpose, students needed to use their previous knowledge, which involves all their background and experiences. Students also recognized their lack of knowledge regarding some subjects presented in the activity, and therefore they were open-minded to learn new things and make additional efforts to increase such knowledge.

Input Response (interpretation task) was also related to "Knowledge". Students are expected to answer specific questions, debate, and critically review a text which implies acquiring new knowledge. After analyzing the data collected from the three instruments, it was possible to observe that students acquired or increased their knowledge of their own culture and also their knowledge of the target language, by means of the designed activities. For instance, in the questionnaire one student said "las actividades nos permitieron conocer un poco más acerca de culturas diferentes” (St. 16. February $18^{\text {th }}$ 2013).

\subsection{Socio-Cultural Competence (Savoir Faire)}

We found that the socio-cultural competence was related to the development activities, which are activities that imply interaction. In the designed activities, this stage was intended to make students reflect, understand and increase their awareness of the differences and similarities between places and cultures. As an example of the 
activities proposed for this stage of the TDA, students were asked to recreate a scene in a museum, to mime and to play a guessing game.

During this stage, students made explicit the importance of interaction between them, taking into account that through others' opinions and perceptions they could build knowledge of the "self" and of "the other". They highlighted the importance of knowing their partners' opinions to reach a better understanding of their social and cultural backgrounds. Students were also aware of the interaction between their culture and the target culture by means of making comparisons. A setting was created in which they could share their experiences and expectations.

\subsection{Attitudes (Savoir Être)}

Attitudes were deduced from what the participants did, since they cannot be spontaneously observed. The students' behaviors seen during the implementation of all the activities emphasized the students' perceptions and thoughts regarding their own and the target culture. It was also observed whether such perceptions and opinions changed during the implementation of the activities.

We realized that the Awareness task activities gave us the opportunity to deduce students' attitudes. During such activities students were asked to give their opinions regarding some pictures that were shown and also to share their points of view in relation to specific topics such as jobs or leisure time in their context and others.

Students' answers were very interesting, taking into account their development of awareness in terms of recognizing values and beliefs in their partners' opinions. They also showed their perceptions and attitudes toward their culture and the importance of appreciating what they had. Students also implicitly recognized that beliefs and attitudes play an important role in cultural awareness.

\subsection{Understanding "the Other"}

Awareness activities were also related to the category "Understanding the other". When students talk about their perceptions on specific topics, their understanding that they are not alone in the world becomes evident.

In general, students showed explicitly how aspects such as tolerance and respect were very important when sharing opinions with others. What is more, they recognized the relevance of understanding others points of view and perceptions regarding different cultures which also contribute to knowledge building. Awareness activities motivated students to know more about other cultures and to understand other perceptions of life. During this process students acquired elements that allowed them to certainly develop cultural awareness.

\subsection{Self-Reflection}

When performing the analysis, we were surprised since this new category called "self-reflection" came out; we also realized that this category has to do with all the other categories. In other words the categories defined in the theoretical framework require or involve "self-reflection". For instance, to talk about knowledge, it was necessary for students to think and reflect about the knowledge they had or lacked. Attitudes or Understanding "the other" are also aspects that students need to thinks and reflect about: how they feel towards the world, what they believe or expect, and they also need to be aware they are not alone in the world.

Having said all this, we are sure that the TDA is a very useful path to design activities to develop cultural awareness since its principles fit perfectly with the categories that emerged to discover cultural awareness. For instance, to give students the opportunity to make comparisons and associate experiences and knowledge, to respect different points of view and perspectives, to appreciate students' experiences and background as a consistent source of learning, to give opportunities to students to interact with others and be part of other students' experiences, to recognize values, to accept we all are different and also to respect heterogeneity. We also consider it important to mention that this approach is intended to humanize learning and in that sense it fits perfectly with the development of cultural awareness.

\section{Conclusion}

Regarding the effectiveness of the TDA as the methodology used to develop cultural awareness, we could affirm that the implementation of such methodology was intended for students to develop their abilities to think, reflect and communicate. Those key aspects are directly bound within the categories that emerged during the analysis 
of the data. The categories of Attitudes and Knowledge were related to the readiness and experiential activities whose purpose was to get learners to think. The category of understanding "the other" and self-reflection were linked to the awareness activities and the purpose was to get students to reflect. Finally, the category of Sociocultural Competence was related to the interpretation tasks and the purpose was for students to communicate.

The students expressed their satisfaction with the written and oral texts used in the activities. Such texts gave them the opportunity to connect their previous experiences with the new information presented, increase their knowledge and practice the language. Students also developed cognitive and affective components and became more sensitive to reality. They also manifested their satisfaction with the way activities were sequenced. On the observation sheets we recorded how students responded to all of the activities and we can say they were two types of activities they liked the most. The first one was the awareness activity, since they had the chance to talk, and share opinions with their peers and also debate and defend their opinions. The second activity they like the most was the development activity, due to the fact, that usually those activities included games or role plays which required production of language and interaction.

We are sure that the TDA is a very useful path to design activities to develop cultural awareness since its principles fit perfectly with the categories that emerged to discover cultural awareness. For instance, to give students the opportunity to make comparisons and associate experiences and knowledge, to respect different points of view and perspectives, to appreciate students' experiences and background as a consistent source of learning, to give opportunities to students to interact with others and be part of other students' experiences, to recognize values, to accept we all are different and also to respect heterogeneity. We also consider it important to mention that this approach is intended to humanize learning and in that sense it fits perfectly with the development of cultural awareness.

It is important to highlight that teaching from a cultural perspective goes beyond teaching content. It is not easy to teach culture. Many teachers and material's developers have decided to base their teaching only on content regarding general cultural information but not on developing intercultural skills.

\section{References}

Bourdieu, P. (1994). Outline of a Theory of Practice. New York: Cambridge University Press.

Byram, M. (1989). Cultural Studies in Foreign Language Education. Clevedon, UK: Multilingual Matters Ltd.

Byram, M. (1997). Teaching and Assessing Intercultural Communicative Competence. Clevedon, UK: Multilingual Matters.

Byram, M., Nichols, A., \& Stevens, D. (2001). Review of Developing Intercultural Competence in Practice.

http://linguistlist.org/issues/12/12-3004.html

Byram, M. (2003). Intercultural Competence. Strasbourg: Council of Europe Publishing.

http://www.coe.int/t/dg4/autobiography/source/aie_en/aie_context_concepts_and_theories_en.pdf

Corbett, J. (2003). An Intercultural Approach to English Language Teaching. Clevedon, UK: Multilingual Matters.

Council of Europe (CEFR) (2001). Common European Framework of Reference for Languages: Learning, Teaching, Assessment. New York: Cambridge University Press.

Hall, B. (2006). Social Movement Learning: Theorizing a Canadian Tradition. In T. Fenwick, T. Nesbit, \& B. Spencer (Eds.), Contexts of Adult Education: Canadian Perspectives (pp. 230-238). Toronto: Thompson Educational Publishers.

Izadpanah, S. (2011) The Review Study: The Place of Culture in English Language Teaching. US-China Foreign Language, 9, 109-116.

Jæger, K. (2001). The Intercultural Speaker and Present-Day Requirements Regarding Linguistic and Cultural Competence. http://inet.dpb.dpu.dk/infodok/sprogforum/Espr19/Jager.pdf

Kramsch, C. J. (1987). Foreign Language Textbooks’ Construction of Foreign Reality. The Canadian Modern Language Review, 44, 95-119.

Kirkeby, C. (2008). The Importance of Language-Learning. http://www.classbrain.com/artteensb/publish/importance_foreign_language.shtml

Lafraya, S. (2011). Intercultural Learning in Non-Formal Education: Theoretical Frameworks and Starting Points. http://www.coe.int/t/dg4/youth/Source/Resources/PR_material/2012_Compendium_Intercultural_Learning_text_en.pdf

Quappe, S., \& Cantatore, G. (2005). What Is Cultural Awareness, Anyway? How Do I Build It? http://www.culturosity.com/articles/whatisculturalawareness.htm

Rico Troncoso, C. (2011). Principled Language Materials for the Development of Intercultural Communicative Competence. PhD Research Thesis, Leeds, UK: Leeds Met University. 
Risager, K. (1998). Language Teaching and the Process of European Integration. In M. Byram, \& M. Fleming (Eds.), Language Learning in Intercultural Perspective: Approaches through Drama and Ethnography (pp. 242-254). Cambridge: Cambridge University Press.

Tomalin, B., \& Stempleski, S. (1993). Cultural Awareness. Hong Kong: Oxford University Press. In Álvarez, J., \& Bonilla, X. (2009). Addressing Culture in the EFL Classroom: A Dialogic Proposal. http://www.scielo.org.co/scielo.php?script=sci_arttext\&pid=S1657-07902009000200011

Tomlinson, B. (2000). Materials for Cultural Awareness: Combining Language, Literature and Culture in the Mind.

Tomlinson, B. (2003). Developing Principled Frameworks for Materials Development. In B. Tomlinson (Ed.), Developing Materials for Language Teaching (pp. 107-129). London UK, Continuum. (Quoted in Rico Troncoso, C. (2011). Principled Language Materials for the Development of Intercultural Communicative Competence. PhD Research Thesis, Leeds, UK: Leeds Met University.) 


\section{Appendix}

Appendix A

\section{Students' questionnaire \\ (Course: Elementary)}

Objetivo: reconocer las percepciones de los estudiantes acerca de las actividades realizadas en clase de acuerdo al libro guía.

Identificar las ideas que tienen los estudiantes sobre su cultura y las trabajadas en clase.

Escoja una sola opción en las preguntas de selección múltiple.

\section{Actividades}

1. ¿Qué opina del contenido trabajado en el libro guía de su nivel de inglés?

2. ¿¿Qué tipo de actividades le gustaría realizar en sus clases de inglés?

\section{Relación entre culturas}

1. ¿¿Para usted qué elementos hay que tener en cuenta a la hora de aprender inglés como segunda lengua?

2. ¿¿Cree usted que el respeto y la tolerancia son elementos importantes a la hora de aprender inglés como segunda lengua?

Sí: No:

¿Porqué?:

3. ¿Es para usted importante conocer otras culturas a parte de la suya?

Sí: ___ No:

¿Porqué?:

4. ¿Es para usted importante reconocer las diferencias o similitudes entre su cultura y las trabajas en su clase de inglés?

Sí: __ No:

¿Porqué?:

5. ¿Con qué frecuencia se encuentra usted con situaciones o actividades que lo hacen pensar en las diferencias o similitudes entre su propia cultura y otras culturas trabajadas en su clase de inglés? 

A. frecuentemente
B. algunas veces
C. raramente
D. nunca
Cuales:

6. ¿Piensa usted que su cultura es más importante que las trabajadas en su clase de inglés?

Sí: No:

¿Por qué?:

\section{Appendix B}

\section{Choosing a Textbook: Questionnaire (part 1)}

\section{Does The Book/Material Suit Your Students?}

1) Is it attractive? Given the average age of your students, would they enjoy using it?

2) Is it culturally acceptable?

3) Does it reflect what you know about your students' needs and interests?

4) Is it about the right level of difficulty?

5) Is it about the right length?

6) Are the course's physical characteristics appropriate?

7) Are there enough authentic materials, so that students can see that the book is relevant to real life?

8) Does it achieve an acceptable balance between knowledge about the language and practice in using the language?

9) Does it achieve an acceptable balance between the relevant language skills, and integrate them so that work in one skill area helps the others?

10) Does the book contain enough communicative activities to enable the students to use the language independently?

\begin{tabular}{|c|c|c|}
\hline YES & PARTLY & $\mathrm{NO}$ \\
\hline YES & PARTLY & $\mathrm{NO}$ \\
\hline YES & PARTLY & $\mathrm{NO}$ \\
\hline YES & PARTLY & $\mathrm{NO}$ \\
\hline YES & PARTLY & $\mathrm{NO}$ \\
\hline YES & PARTLY & $\mathrm{NO}$ \\
\hline YES & PARTLY & $\mathrm{NO}$ \\
\hline YES & PARTLY & $\mathrm{NO}$ \\
\hline YES & PARTLY & $\mathrm{NO}$ \\
\hline YES & PARTLY & $\mathrm{NO}$ \\
\hline
\end{tabular}

NO

$\mathrm{NO}$

$\mathrm{NO}$

NO

NO

NO

$\mathrm{NO}$

NO

$\mathrm{NO}$

$\mathrm{NO}$

Score: 2 points for every YES answer/1point for every PARTLY answer/0 for every NO answer.

Choosing a Textbook: Questionnaire (part 2)

Does The Book/Material Suit The Teacher?

\begin{tabular}{|c|c|c|c|}
\hline $\begin{array}{l}\text { 1) Is your overall impression for } \\
\text { the contents and layout of the } \\
\text { course favorable? }\end{array}$ & YES & PARTLY & $\mathrm{NO}$ \\
\hline $\begin{array}{l}\text { 2) Is there a good, clear teacher's } \\
\text { guide with answers and help on } \\
\text { methods and additional activities? }\end{array}$ & YES & PARTLY & NO \\
\hline
\end{tabular}




\section{Continued}

3) Can one use the book in the classroom without constantly having to turn to the teacher's guide?

4) Are the recommended methods and approaches suitable for you, your students and your classroom?

5) Are the approaches easily adaptable if necessary?

6) Does using the course require little or no time-consuming preparation?

7) Are useful ancillary materials such as tapes, workbooks, and visuals provided?

8) Is there sufficient provision made for tests and revision?

9) Does the book use a "spiral" approach, so that the items are regularly revised and used again in different contexts?

10) Is the course appropriate for, and liked by, colleagues?

Score: 2 points for every YES answer/1point for every PARTLY answer/0 for every NO answer.

\section{Choosing a Textbook: Questionnaire (part 3)}

\section{Does The Book/Material Suit The Syllabus And Examination?}

\begin{tabular}{|c|c|c|c|}
\hline $\begin{array}{l}\text { 1. Has the book/material been } \\
\text { recommended or approved by the } \\
\text { authorities? }\end{array}$ & YES & PARTLY & NO \\
\hline $\begin{array}{l}\text { 2. Does the book/material follow } \\
\text { the official syllabus in a creative } \\
\text { manner? }\end{array}$ & YES & PARTLY & NO \\
\hline $\begin{array}{l}\text { 3. Is the course well-graded, so } \\
\text { that it gives well-structured and } \\
\text { systematic coverage of the } \\
\text { language? }\end{array}$ & YES & PARTLY & NO \\
\hline $\begin{array}{l}\text { 4. If it does more than the syllabus } \\
\text { requires, is the result and } \\
\text { improvement? }\end{array}$ & YES & PARTLY & NO \\
\hline $\begin{array}{l}\text { 5. Are the activities, contents and } \\
\text { methods, used in the course } \\
\text { well-planned and executed? }\end{array}$ & YES & PARTLY & NO \\
\hline $\begin{array}{l}\text { 6. Has it been prepared } \\
\text { specifically for the target } \\
\text { examination? }\end{array}$ & YES & PARTLY & NO \\
\hline $\begin{array}{l}\text { 7. Do the course's methods help } \\
\text { the students prepare for the exam? }\end{array}$ & YES & PARTLY & NO \\
\hline $\begin{array}{l}\text { 8. Is there a good balance between } \\
\text { what the examination requires, } \\
\text { and what the students need? }\end{array}$ & YES & PARTLY & NO \\
\hline $\begin{array}{l}\text { 9. Is there enough examination } \\
\text { practice? }\end{array}$ & YES & PARTLY & NO \\
\hline $\begin{array}{l}\text { 10. Does the course contain useful } \\
\text { hints on examination technique? }\end{array}$ & YES & PARTLY & NO \\
\hline
\end{tabular}

Score: points for every YES answer/1point for every PARTLY answer/0 for every NO answer. 


\section{Appendix C (Audio)}

\section{Appendix D}

\section{Formulario de consentimiento \\ Formulario de consentimiento para trabajo de grado Título: Diseño de actividades bajo para desarrollar la conciencia cultural}

\section{Nombres de las investigadoras: Susan Sarmiento-Laura Cardona Facultad: Comunicación y lenguaje}

\section{Información}

Nuestro trabajo de grado pretende desarrollar la conciencia cultural en los estudiantes de Inglés Elemental de la Lic. Lenguas Modernas de la Pontificia Universidad Javeriana. Para llevar a cabo dicho trabajo, es necesario aplicar un número de actividades diseñadas por las investigadoras siguiendo algunos parámetros metodológicos para el desarrollo de dicha conciencia. Para ello solicitamos diligenciar el siguiente cuestionario. Agradecemos su amable colaboración

\section{Señale con una $(x)$ para confirmar}

\begin{tabular}{|c|c|}
\hline Estoy de acuerdo con participar en este proyecto de investigación. & Si_No_ \\
\hline $\begin{array}{l}\text { He leído el formulario de consentimiento y la información sobre la investigación, y tuve la oportunidad de hacer } \\
\text { preguntas sobre la misma. }\end{array}$ & $\mathrm{Si}_{-} \mathrm{No}_{-}$ \\
\hline He sido informado/a y he entendido el propósito de esta investigación. & Si_No_ \\
\hline $\begin{array}{l}\text { Estoy de acuerdo con que toda la información que dé será usada en esta investigación y mi privacidad será } \\
\text { respetada. }\end{array}$ & Si_No_ \\
\hline Alguna información que pueda identificarme potencialmente no se usará en material publicado. & Si_ No_ \\
\hline $\begin{array}{l}\text { Entiendo que no estoy obligado/a a ser parte de este estudio y que puedo retirarme en cualquier momento sin } \\
\text { ningún tipo de perjuicio. }\end{array}$ & Si_No_ \\
\hline
\end{tabular}

\section{Nombrecompleto:}

C.C/T.I:

Fecha:

Nivel de inglés:

Firma:

\section{Appendix E}

A summary of the Text-driven framework (Tomlinson, 2003)

Taken from: Rico Troncoso (2011)

\begin{tabular}{|c|c|c|c|}
\hline STAGE & PROCEDURE & PRINCIPLES & OBJECTIVES \\
\hline $\begin{array}{l}\text { TEXT } \\
\text { COLLECTION }\end{array}$ & $\begin{array}{l}\text { Find or create potentially engaging } \\
\text { texts (written or spoken) }\end{array}$ & $\begin{array}{l}\text { Affective engagement is a prerequisite } \\
\text { for durable learning. }\end{array}$ & $\begin{array}{l}\text { To build a library of texts with the } \\
\text { potential for engaging learners. }\end{array}$ \\
\hline TEXT SELECTION & $\begin{array}{l}\text { Select a text suitable in level and } \\
\text { theme for your target learners. }\end{array}$ & Text need to be matched with learners. & $\begin{array}{l}\text { To find a text with the potential for } \\
\text { useful engagement for the target } \\
\text { learners. }\end{array}$ \\
\hline TEXT EXPERIENCE & $\begin{array}{l}\text { Read or listen to the text } \\
\text { experientially. }\end{array}$ & $\begin{array}{l}\text { Apprehension should come before } \\
\text { comprehension. }\end{array}$ & $\begin{array}{l}\text { To start from an experience which } \\
\text { you can try to help the learners to } \\
\text { approximate. }\end{array}$ \\
\hline $\begin{array}{l}\text { READINESS } \\
\text { ACTIVITIES }\end{array}$ & $\begin{array}{l}\text { Devise activities which could help } \\
\text { the learners achieve mental } \\
\text { readiness for experiencing the text. }\end{array}$ & $\begin{array}{l}\text { Experiencing a text is a } \\
\text { multidimensional process involving } \\
\text { sensory imaging, inner speech and the } \\
\text { establishment of affective and } \\
\text { cognitive connections. }\end{array}$ & $\begin{array}{l}\text { To help the learners to experience a } \\
\text { target language text in the } \\
\text { multidimensional way they would } \\
\text { automatically use when } \\
\text { experiencing a L1 text. }\end{array}$ \\
\hline $\begin{array}{l}\text { EXPERIENTIAL } \\
\text { ACTIVITIES }\end{array}$ & $\begin{array}{l}\text { Devise whilst-reading or listening } \\
\text { activities which help de learners to } \\
\text { process the text in an experiential } \\
\text { way. }\end{array}$ & $\begin{array}{l}\text { L2 learners tend to process a text in a } \\
\text { studial way in an insecure attempt to } \\
\text { achieve total comprehension. }\end{array}$ & $\begin{array}{l}\text { To help the learners to move away } \\
\text { from their tendency to study texts so } \\
\text { that they can engage with the text } \\
\text { instead experientially. }\end{array}$ \\
\hline
\end{tabular}




\section{Continued}

\begin{tabular}{|c|c|c|c|}
\hline $\begin{array}{l}\text { INTAKE RESPONSE } \\
\text { ACTIVITIES }\end{array}$ & $\begin{array}{l}\text { Devise activities which help the } \\
\text { learners to articulate and develop } \\
\text { their mental representations of the } \\
\text { text. }\end{array}$ & $\begin{array}{l}\text { Learning is facilitated by starting } \\
\text { positively from what the learners do } \\
\text { know and understand. }\end{array}$ & $\begin{array}{l}\text { To encourage learners to process } \\
\text { their representations of a text rather } \\
\text { than the text itself and to encourage } \\
\text { them to be relaxed and confident in } \\
\text { their response to text. }\end{array}$ \\
\hline $\begin{array}{l}\text { DEVELOPMENT } \\
\text { ACTIVITIES }\end{array}$ & $\begin{array}{l}\text { Devise activities which help the } \\
\text { learners to use their representations } \\
\text { of the text as a basis for language } \\
\text { production activities. }\end{array}$ & Mental connections facilitate learning. & $\begin{array}{l}\text { To help learners to express } \\
\text { themselves in the target language } \\
\text { intelligently and creatively. }\end{array}$ \\
\hline $\begin{array}{l}\text { INPUT RESPONSE } \\
\text { ACTIVITIES }\end{array}$ & $\begin{array}{l}\text { Devise activities which help the } \\
\text { learners to go back to the text and } \\
\text { to discover patterns and regularities } \\
\text { of language use in the text. }\end{array}$ & $\begin{array}{l}\text { A good time to analyze a text is just } \\
\text { after and enjoyable multidimensional } \\
\text { experience of it. Helping learners to } \\
\text { make discoveries for themselves can } \\
\text { be an effective way of promoting } \\
\text { long-term learning. }\end{array}$ & $\begin{array}{l}\text { To get the learners to develop their } \\
\text { analytical skills and their ability to } \\
\text { make discoveries about the use of } \\
\text { the target language themselves. }\end{array}$ \\
\hline TRAILLING & $\begin{array}{l}\text { Try out the materials with a typical } \\
\text { target class. }\end{array}$ & $\begin{array}{l}\text { Matching materials to learner needs } \\
\text { and wants is an ongoing process. }\end{array}$ & $\begin{array}{l}\text { To find out how usable and } \\
\text { motivating materials are. }\end{array}$ \\
\hline EVALUATION & $\begin{array}{l}\text { Use questionnaires, interviews and } \\
\text { analysis of the learner's work to } \\
\text { find out what effect the materials } \\
\text { had on the learners. }\end{array}$ & $\begin{array}{l}\text { Giving learners a chance to evaluate } \\
\text { their learning process can not only } \\
\text { provide useful information but can } \\
\text { also motivate and stimulate learners. }\end{array}$ & $\begin{array}{l}\text { To show learners they are respected } \\
\text { and to find out what effect the } \\
\text { materials had on them. }\end{array}$ \\
\hline REVISION & $\begin{array}{l}\text { Produce and improved version of } \\
\text { the materials. }\end{array}$ & $\begin{array}{l}\text { Materials developers and teachers need } \\
\text { constantly to improve their materials } \\
\text { to achieve a closer match with learner } \\
\text { needs and wants. }\end{array}$ & $\begin{array}{l}\text { To match the needs and wants of the } \\
\text { learners. }\end{array}$ \\
\hline
\end{tabular}

\section{Appendix F}

Activity 1

\section{CITIES}

Objective: Students will reflect on differences about their city and other cities of the world, understanding such differences and increasing their awareness of the difference with other places and cultures.

\section{Text Collection}

Text taken from: https://en.wikipedia.org/wiki/British_Museum

\section{Text Selection}

\section{Reading comprehension-British Museum}

\section{Text Experience}

In this stage we re-engage with the text, so we can design an activity that arouses in elementary English students thoughts and reflections. Without this stage we may only focus our attention in just linguistic structures.

\section{Readiness Activities}

1) What image do you like the most and why?

2) Share your answer with your partner
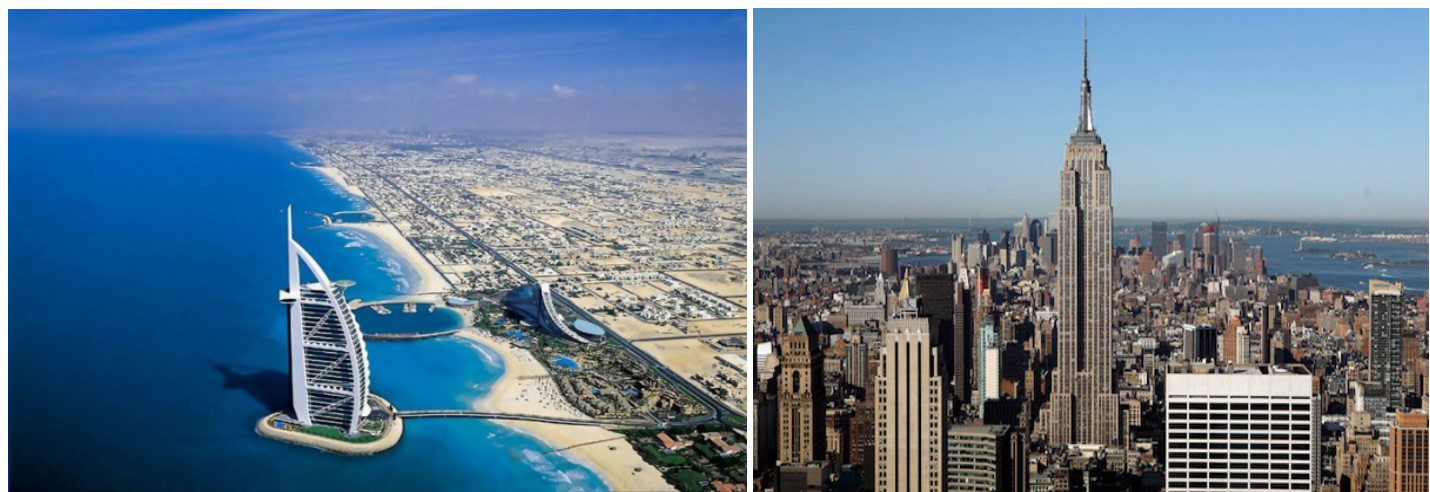

Burj Al Arab, Dubai Empire State Building, NY, USA 


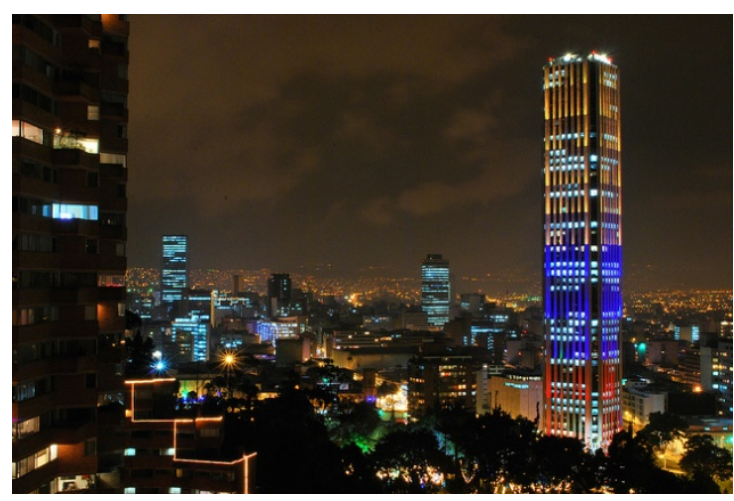

Colpatria Tower, Bogotá, Colombia

3) Share with your classroom the importance of this kind of building for a country.

\section{Experiential Activities}

4) Read the text

5) Fill in the blanks with the right word from the box

\begin{tabular}{|c|c|c|c|c|}
\hline buildings & manuscripts & including & collection & important \\
\hline popular & visitors & pieces & culture & continents \\
\hline
\end{tabular}

THE BRITISH MUSEUM

The British Museum in London is one of the world's largest and most important museums which illustrates human history and culture from its beginning to the present. As with all other national museums and art galleries in Britain, the Museum charges no admission fee.

The British Museum set up in 1753 and opened in 1759. It was the first museum in the world to be open to everyone. The museum gradually grew over the next two hundred years. It has nearly six million visitors a year and is the second most popular art museum in the world. Some of the museum's most popular and important exhibits include the Rosetta Stone and Lindow man.

The history of the British Museum began with the English physicist Hans Sloane, who died aged 93 in 1753. During his life, he had collected many important things from all around the world. When he died, he did not want his collection to be split up between his relatives. He sold his collection to the parliament of King George II. The parliament set up the British Museum to hold the collection. By the time he died, Sloane had collected over 80,000 objects from all over the world including Egypt, Greece, Rome and the Americas. The collection was mostly books and manuscripts but there were many important archaeological pieces included as well.

The government looked at many possible places to build the new museum, including Buckingham House, which later became Buckingham Palace. Eventually a building called Montagu House was chosen. Over the years, more buildings were added to hold the new historic objects, sculptures, and important discoveries.

As new collections and books were brought in, including Roman British, Ancient Greek and Ancient Egyptian arte facts, as well as curiosities from many other cultures and times around the world, it was split into many parts, called departments. These have changed many times over the years and are often merged together, split into smaller departments or renamed and changed altogether.

Today the museum no longer houses books and manuscripts it once held since now they form part of the independent British Library. Nevertheless, it preserves its universality in its collections of more than seven million arte facts from all continents, representing the cultures of the world, ancient and modern.

\section{Input Response Activity Interpretation task}

6) Comprehension Questions about The Reading

- The museum contains:

a) Many objects from London 

b) Many objects from all around the world
c) Many objects from Buckingham Palace
d) None of the above

- The objects in the museum came from:

a) King George's II personal collection

b) The parliament's personal collection

c) Hans Sloane's personal collection

d) None of the above

- The collection was not divided because:

a) It was mostly old books and manuscripts

b) It was sold by the parliament to the king

c) It was sold to Egypt, Greece, Rome and the Americas

d) None of the above

- The new museum was built at the:
a) Buckingham House
b) Buckingham Palace
c) Montagu House
d) None of the above

- What is the main idea of the reading:

a) Let the reader know that the objects at the museum came from Hans Sloan

b) Let the reader know about the history of the British Museum

c) Make the readers understand the museum contains objects from all around the world.

d) None of the above

\section{Awareness activities}

7) What aspects do you consider important when visiting a place for the very first time? Write just four words

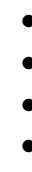

8) What would you say/advise to a person who is visiting a place in your country for the first time?

9) Compare your answers with your partner and agree on the advice.

\section{Intake Response Activities}

10) In pair establish similarities and differences between The British Museum and the other ones you have been before

\begin{tabular}{ll}
\hline The British Museum & $\bullet$ One you have visited \\
\hline$\bullet$ & $\bullet$ \\
\hline & \\
\hline
\end{tabular}

\section{Development Activities}

11) In small groups you are going to re-create a scene of a museum where one of you is the guide and the others are tourists from different parts of the world. Here you have a chart that may guide your performance.

\begin{tabular}{lc}
\hline \multicolumn{1}{c}{ Guide } & Tourists \\
\hline $\begin{array}{c}\text { Describe the master piece } \\
\text { Answer the tourists' questions }\end{array}$ & Tell to the group your name/age/ nationality \\
\hline
\end{tabular}




\section{Continued}

\begin{tabular}{ll}
\hline Museum Guide (vocabulary) & \multicolumn{1}{c}{ Tourist (expressions) } \\
\hline $\begin{array}{ll}\text { Simple, subtle, dramatic, geometric large, small, vibrant, natura- } \\
\text { listic, symmetric, pale, enigmatic }\end{array}$ & $\begin{array}{l}\text { My name is __t'm } \\
\text { would like to know... -who is the author? -what does it represent? } \\
\text {-when was it made? -I think this piece is... } \\
\text { Use adjectives to give your opinion. }\end{array}$ \\
\hline
\end{tabular}

\section{Appendix G}

\section{Activity 2}

\section{Jobs and Places of Work}

Objective: Students express their perceptions and reflect on the differences and similarities among jobs and places of work around the world, increasing their awareness on the individuality of their insights and of others'.

\section{Text Collection}

Text taken from: http://www.elllo.org/PagesMixer/08-MX-DreamJob.htm

\section{Text Selection}

Listening—Dream Job

\section{Text Experience}

In this stage we re-engage with the text, so we can design an activity that arouses in elementary English students thoughts and reflections. Without this stage we may only focus our attention in just linguistic structures.

\section{Readiness Activities}

1) Listening the following song http://www.youtube.com/watch?v=mFe5Ac01eMc

\section{"She's not just a pretty face" Shania Twain}

(Oh na, na, na)

She hosts a T.V. show--she rides the rodeo

She plays the bass in a band She's an astronaut--

a valet at the parking lot

A farmer working the land

She is a champion--she gets the gold

She's a ballerina--the star of the show

\section{[Chorus:]}

She's--not--just a pretty face

She's--got--everything it takes

She has a fashion line--

a journalist for "Time"

Coaches a football team

She's a geologist--a romance novelist

She is a mother of three

She is a soldier--she is a wife

She is a surgeon--she'll save your life

\section{[Chorus:]}

She's--not--just a pretty face

She's--got--everything it takes

She's--mother--of the human race

She's--not--just a pretty face

Oh, oh, yeah

Oh na, na, na, na......

She is your waitress--she is your judge-- 
she is your teacher

She is every woman in the world

$$
\text { Oh, la, la, la }
$$

She flies an airplane--

she drives a subway train

At night she pumps gasoline

She's on the council--she's on the board

She's a politician--she praises the Lord

[Repeat Second Chorus]

No, she's (she's) not (not)--

just a pretty face

She's (she's) got (got)--everything it takes

She's--not--just a pretty face

She's got everything it takes

She's not just a pretty face

2) What came to your mind when you heard the song? Share with the group.

\section{Experiential Activities}

3) Listen to the audio.

http://www.elllo.org/PagesMixer/08-MX-DreamJob.htm

\section{Script:}

\section{Tres, United States}

My dream job, absolute best job in the world, would be working for Bill Gates, and being able to give my advice for a price. He asks me what I think about Longhorn, it sucks, redo it, I get a few million. What do I think about the new apple computers, or OS, it's great, we should copy it don't get caught. I get millions. How could you ask for anything more?

\section{Naomi, Australia}

My dream job would be to work at the United Nations. I would like to work there because I could work in a very multi-cultural environment and I would be allowed to travel a lot and experience many different types of countries and lifestyles.

\section{Alan, Canada}

Ah, my dream job, well, I would like to be an NHL hockey player, and All-Star in the NHL, getting paid millions of dollars a year, scoring a lot of goals. Having lots of people honor me and look up to me and just be a good hockey player.

\section{Anita, Taiwan}

What is my dream job? My dream job is to work in the mass-communication company and I think I'm a very creative person, so I would like to do a job, a very creative job so I think a mass-communication company can let me, let me provide those creative thoughts and ideas.

\section{Jim, England}

Um, my dream job would involve first of all, very, very high salary. I would start work at about 10 am, lunch at 12 for 2 hours, and then work in the afternoon until 4. I think I would spend half the year in the Northern Hemisphere, and then half the year in the Southern Hemisphere, just so I could have summer all year long.

\section{Kate, New Zealand}

My dream job is have my own business. At the moment, I'm really into snowboarding and so I'd love to have a snowboarding tour company. Every year I'm going snowboarding, and I have a lot of experience in teaching snowboarding, instructing, and also I'm at university now so I'm learning how to run my own business, and accounting, et cetera, so I'd love to be a snowboarding, to own my own snowboarding tour company.

\section{Input Response Activity}

Interpretation task

4) Complete the chart with the information requested about each person 


\begin{tabular}{|c|c|c|c|}
\hline Name & Country & Dream Job & Reason \\
\hline Tres & United States & Working for Bill Gates and give advice & $\begin{array}{l}\text { He would love to make a lot of money just by } \\
\text { giving his opinion }\end{array}$ \\
\hline Naomi & Australia & To work at the United Nations & $\begin{array}{l}\text { She'd have the possibility to work in a } \\
\text { multicultural environment and travel a lot. }\end{array}$ \\
\hline Alan & Canada & To be and NHL hockey player & $\begin{array}{l}\text { To be paid millions of dollars a year and having } \\
\text { people honor him }\end{array}$ \\
\hline Anita & Taiwan & To work in the mass- communication company & To perform a very creative job \\
\hline Jim & England & (not mentioned) & To have a good salary, flexibility and traveling \\
\hline Kate & New Zealand & To have her own business & $\begin{array}{c}\text { She loves snowboarding, is an instructor and is } \\
\text { also learning to run a business }\end{array}$ \\
\hline
\end{tabular}

\section{Awareness activities}

5) What is your dream job and why?

6) Which country would you like to have that dream job? Explain why you chose that country.

7) Share your answers with your partners and tell the group what you think about your partner's answers?

8) What do you think about these pictures?

\section{Intake Response Activities}

9) Compare in pairs your dream jobs and state 3 similarities and 3 differences on how they are done in your country and in another country

Ex: Similarities and differences of being a policeman in Colombia and in India.

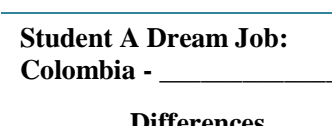

Differences
Student B Dream Job:

Colombia -

Differences
Similarities

\section{Development Activities}

10) One person from each group has to do mimics representing one job. The same group has to guess it

11) In groups students look for the jobs in the following word soup.

\begin{tabular}{|c|c|c|c|c|c|c|c|c|c|c|c|c|c|c|}
\hline $\mathbf{J}$ & $\mathbf{U}$ & D & $\mathbf{G}$ & $\mathbf{E}$ & B & $\mathbf{A}$ & $\mathbf{R}$ & $\mathbf{M}$ & $\mathbf{A}$ & $\mathbf{N}$ & $\mathbf{G}$ & $\mathbf{R}$ & $\mathbf{P}$ & $\mathbf{U}$ \\
\hline $\mathbf{Q}$ & $\mathbf{R}$ & $\mathbf{A}$ & $\mathbf{T}$ & $\mathbf{V}$ & $\mathbf{Y}$ & $\mathbf{R}$ & $\mathbf{E}$ & $\mathbf{K}$ & $\mathbf{A}$ & B & $\mathbf{N}$ & $\mathbf{N}$ & $\mathbf{Q}$ & $\mathbf{J}$ \\
\hline $\mathbf{E}$ & $\mathbf{H}$ & C & C & $\mathbf{T}$ & $\mathbf{E}$ & $\mathbf{Y}$ & $\mathbf{E}$ & $\mathbf{P}$ & $\mathbf{A}$ & $\mathbf{R}$ & $\mathbf{G}$ & D & $\mathbf{Y}$ & $\mathbf{O}$ \\
\hline $\mathbf{K}$ & $\mathbf{J}$ & $\mathbf{T}$ & $\mathbf{H}$ & $\mathbf{U}$ & G & $\mathbf{T}$ & $\mathbf{A}$ & C & $\mathbf{R}$ & $\mathbf{T}$ & $\mathbf{U}$ & I & D & $\mathbf{U}$ \\
\hline $\mathbf{L}$ & $\mathbf{K}$ & O & $\mathbf{E}$ & $\mathbf{J}$ & $\mathbf{U}$ & $\mathbf{R}$ & $\mathbf{N}$ & $\mathbf{E}$ & $\mathbf{E}$ & $\mathbf{U}$ & $\mathbf{Q}$ & $\mathbf{V}$ & O & $\mathbf{R}$ \\
\hline A & $\mathbf{L}$ & $\mathbf{R}$ & $\mathbf{F}$ & I & $\mathbf{R}$ & $\mathbf{E}$ & $\mathbf{M}$ & A & $\mathbf{N}$ & $\mathrm{S}$ & $\mathbf{L}$ & $\mathbf{T}$ & C & $\mathbf{N}$ \\
\hline W & $\mathbf{Y}$ & $\mathbf{I}$ & $\mathbf{P}$ & $\mathbf{P}$ & $\mathbf{R}$ & $\mathbf{E}$ & $\mathbf{H}$ & C & $\mathbf{A}$ & $\mathbf{E}$ & $\mathbf{T}$ & $\mathbf{E}$ & $\mathbf{T}$ & $\mathbf{A}$ \\
\hline $\mathbf{Y}$ & $\mathbf{K}$ & $\mathbf{I}$ & $\mathbf{O}$ & $\mathbf{J}$ & $\mathbf{A}$ & $\mathbf{R}$ & $\mathbf{G}$ & $\mathbf{O}$ & $\mathbf{L}$ & $\mathbf{I}$ & $\mathbf{K}$ & $\mathbf{R}$ & O & $\mathbf{L}$ \\
\hline $\mathbf{E}$ & $\mathbf{R}$ & $\mathbf{E}$ & $\mathrm{S}$ & $\mathrm{S}$ & $\mathbf{E}$ & $\mathbf{R}$ & D & $\mathbf{R}$ & I & $\mathbf{A}$ & $\mathbf{H}$ & $\mathbf{O}$ & $\mathbf{R}$ & I \\
\hline $\mathbf{R}$ & $\mathbf{Y}$ & $\mathbf{J}$ & $\mathbf{R}$ & $\mathbf{E}$ & $\mathbf{Y}$ & A & $\mathbf{E}$ & $\mathbf{R}$ & $\mathbf{O}$ & $\mathbf{L}$ & $\mathbf{O}$ & C & $\mathbf{O}$ & $\mathrm{S}$ \\
\hline $\mathbf{Y}$ & $\mathbf{O}$ & $\mathbf{P}$ & $\mathbf{H}$ & O & $\mathbf{T}$ & O & G & $\mathbf{R}$ & $\mathbf{A}$ & $\mathbf{P}$ & $\mathbf{H}$ & $\mathbf{E}$ & $\mathbf{R}$ & $\mathbf{T}$ \\
\hline $\mathbf{W}$ & $\mathbf{R}$ & $\mathbf{J}$ & $\mathbf{R}$ & $\mathbf{T}$ & $\mathbf{N}$ & $\mathbf{U}$ & $\mathbf{R}$ & $\mathrm{S}$ & $\mathbf{E}$ & $\mathbf{Y}$ & $\mathbf{Q}$ & $\mathbf{U}$ & $\mathbf{E}$ & $\mathbf{N}$ \\
\hline
\end{tabular}




\section{Appendix $\mathbf{H}$}

\section{Activity 3}

Text Collection

\section{Leisure Time}

Text taken from: http://www.elllo.org/english/Games/G019-Movie.html

Text Selection

Listening-Movies

Text Experience

In this stage we re-engage with the text, so we can design an activity that arouses in elementary English students thoughts and reflections. Without this stage we may only focus our attention in just linguistic structures.

\section{Readiness Activities}

1) Look at the video and answer the questions

http://www.youtube.com/watch?v=NX7QNWEGcNI

2) Would you do Parkour? Why? Share your answer

\section{Experiential Activities}

3) In groups listen to the audio and identify the name of the movies and answer the questions. http://www.elllo.org/english/Games/G019-Movie.html

\section{Script:}

What's that movie? It's a science fiction, like fantasy movie and it takes place in this magical world and it's about the, I think three or four children, they go into this fantasy world through some piece of furniture in their house, like through their dresser or something and they meet up with giants and dwarves, like little people and talking beasts and all these fantasy creatures like that. (Narnia)

- Why type of movie is it?

- What happens in the movie?

I think this was the most popular movie of 2005. It's a science fiction movie and it takes place in outer space but actually the story is more like a drama. It's about a guy who has a secret wife and she's pregnant and he's worried that she'll die while giving birth so he does anything he can to prevent her death including turning to the dark side. (Star Wars)

- This movie was the most popular or what year?

- Where does this movie take place?

Oh, I saw this movie. Brad Pitt is in it, and it's a romantic sort of action movie and it's about a couple who seem to have normal lives but actually in secret life they are assassins. They kill people. That's their job, and eventually they're hired to kill each other even though they are a couple and they're married. They're employed to try to assassinate each other. (Mr. and Mrs. Smith)

- What type of movie is it?

- What is the movie about?

I don't like crime stories so much, but this one I saw and it's a pretty good movie. Christian Bale is in it and it takes place in a big city. This major metropolis, and this kids parents were killed when he was young and he decides that he's going to get revenge against the criminals in this city. He does this training program and he creates this special suite and he uses all kinds of high tech weapons to fight all of the evil forces in the city so he's, he's this major crime fighter. (Batman)

- Where does this movie take place?

- What is mentioned about the movie?

I didn't see this one but it got pretty good reviews and a lot of people said it was really funny. It's like an action adventure comedy and it takes place in a New York Zoo and later one they go an African island and it's about this group, this group of animals who live in the zoo and the penguins decide that want to lead everyone out, so the animals escape from the zoo and they go on a journey to find out what it's like to live in the wild again. (Madagascar)

- What did the people say about the movie?

- Where does this movie take place and who are the main characters?

This one's a sci-fi film. Sci-fi is short for science fiction and it takes place, I think, yeah, it takes place in the 
U.S. and it's in the future. Tom Cruise is in it and it's about the earth being attacked by aliens. (War of the Worlds)

- What is Sci-fi?

- Where does it take place and what is about?

\section{Input Response Activity}

Interpretation task

4) The questions above correspond to the ones for the Interpretation task

Awareness activities

5) What do you do in your free time? Why?

6) What leisure time activities do you think a French person do? Why?

7) Where do you prefer to develop your best leisure time activity? Any region or country in particular? Explain briefly

8) Share your answers with your partner.

Intake Response Activities

9) Look carefully the images. What do you think about these two images?
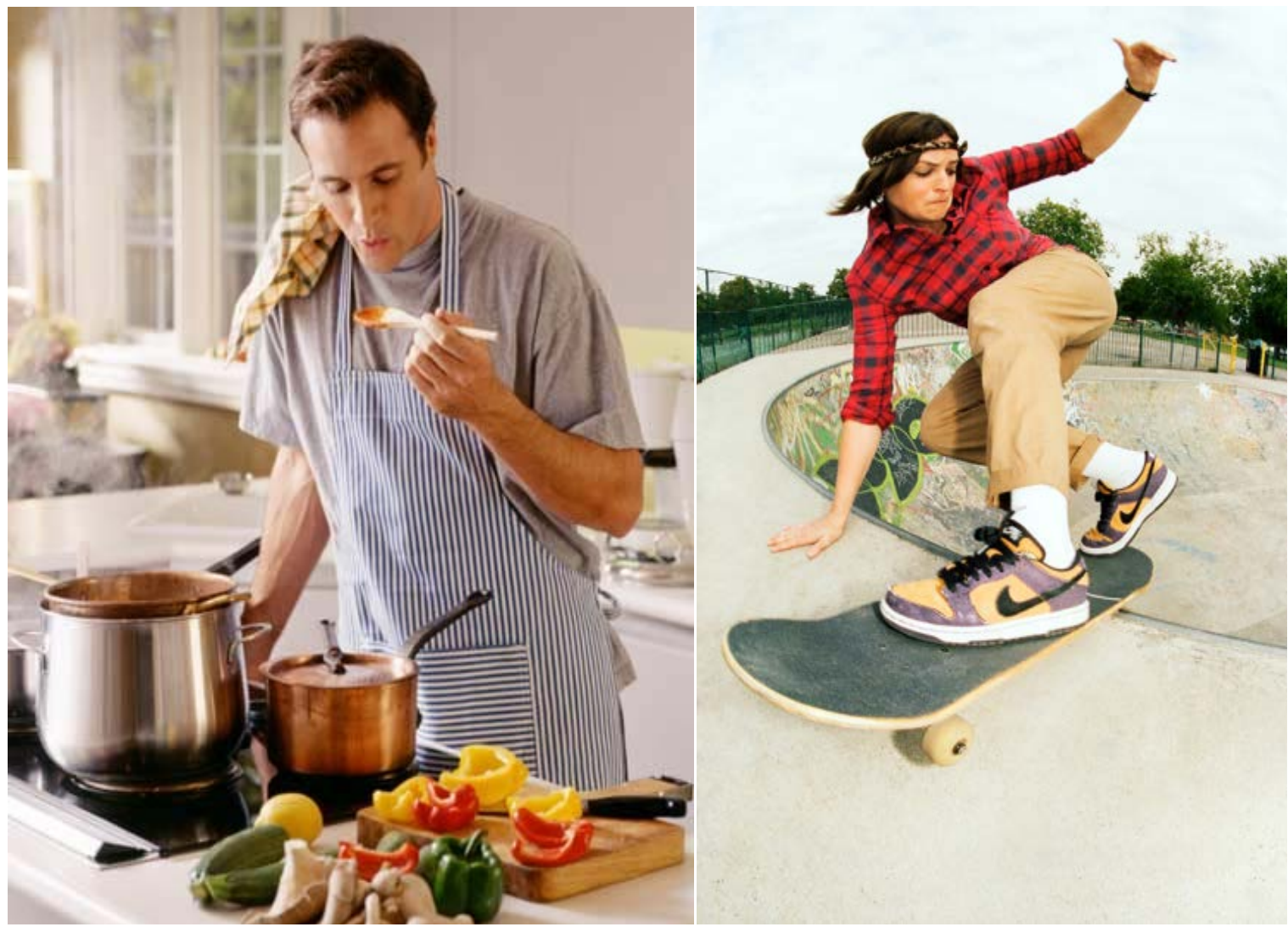

10) Share your answer.

\section{Development Activities}

11) Students write a leisure activity in a piece of paper and stick the paper on the forehead of a partner who has 
to guess the leisure activity by making only yes and no questions.

\section{Appendix I}

Objetivos:

\section{Cuestionario investigativo para los estudiantes \\ (Inglés elemental) \\ Diseño de actividades para desarrollar la conciencia cultural}

- Desarrollar la conciencia cultural de los estudiantes de elemental por medio de actividades diseñadas bajo los parámetros del Text-Driven Approch.

1. ¿ ¿Te llamaron la atención las actividades realizadas el día de hoy?
- Sí
No__ Explica brevemente tu respuesta

$-$

2. ¿ ¿Te gustó la forma en la que se desarrollaron las actividades durante la clase?

- Sí__ No__ Explica brevemente tu respuesta

3. ¿De todas las actividades realizadas en clase, hubo alguna que te causara más dificultad que las otras? ¿cuál?

- Sí__ No__ Explica brevemente tu respuesta

$-$

$-$

$-$

$-$

4. ¿Las actividades te permitieron pensar en tu cultura?

- Sí_ N No_ Explica brevemente tu respuesta

$-$

$-$

5. ¿Las actividades te permitieron socializar con tus compañeros y ver otros puntos de vista?

- Sí__ No_ Explica brevemente tu respuesta

6. ¿Crees que es importante conocer el punto de vista de tus compañeros?

- Sí__ No__ Explica brevemente tu respuesta

$-$

$-$

7. ¿Las actividades que realizaste te permitieron pensar en algún valor social o cultural? ¿Cuál? Explicabrevementeturespuesta

$-$

$-$

8. ¿Las actividades te permitieron afianzar o cambiar alguna de tus creencias? ¿Cuál? Explicabrevementeturespuesta

- ¿ ¿Qué sugerencia harías para mejorar o implementar futuras actividades? 
Appendix L
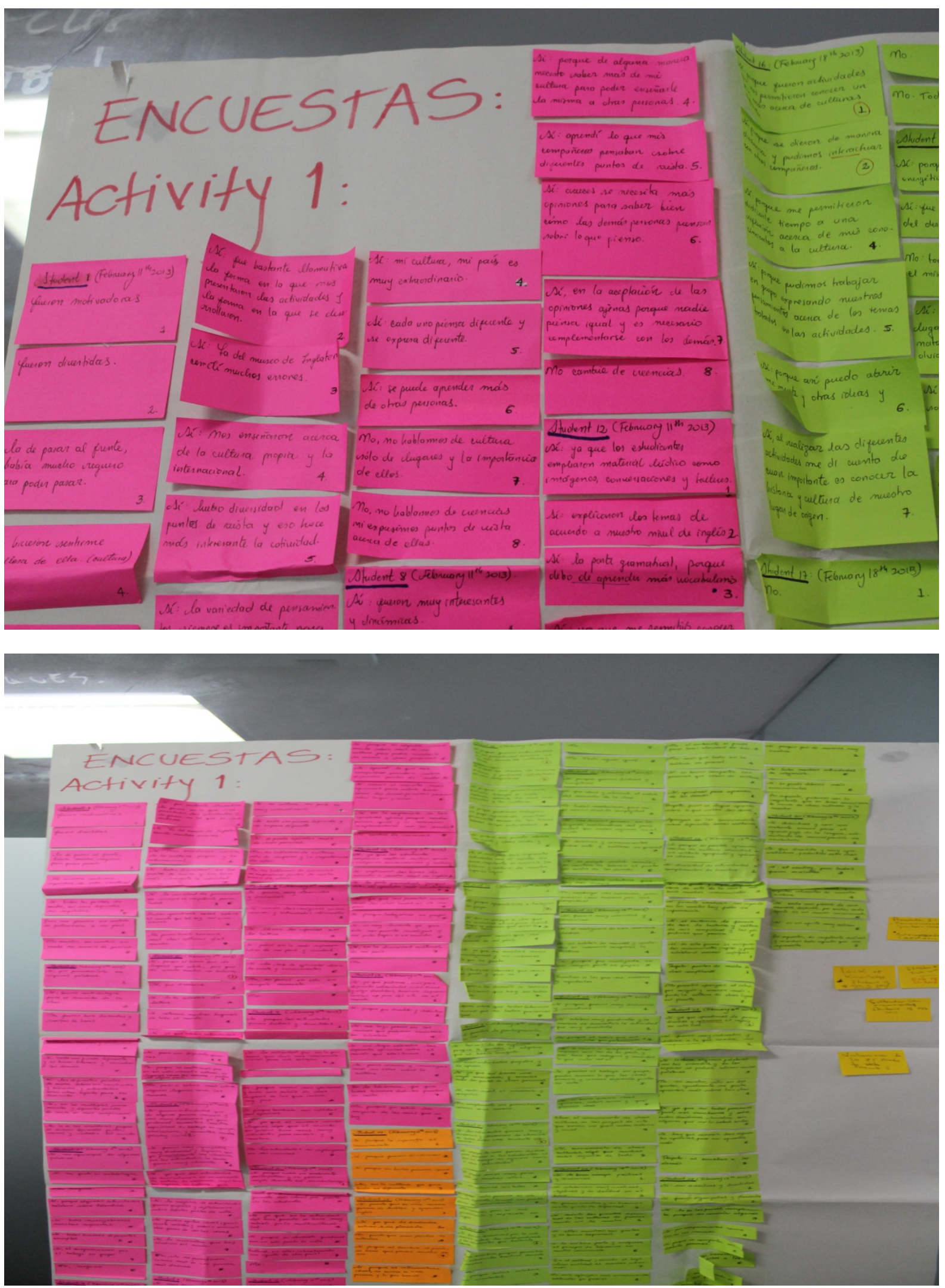
L. Cardona et al.

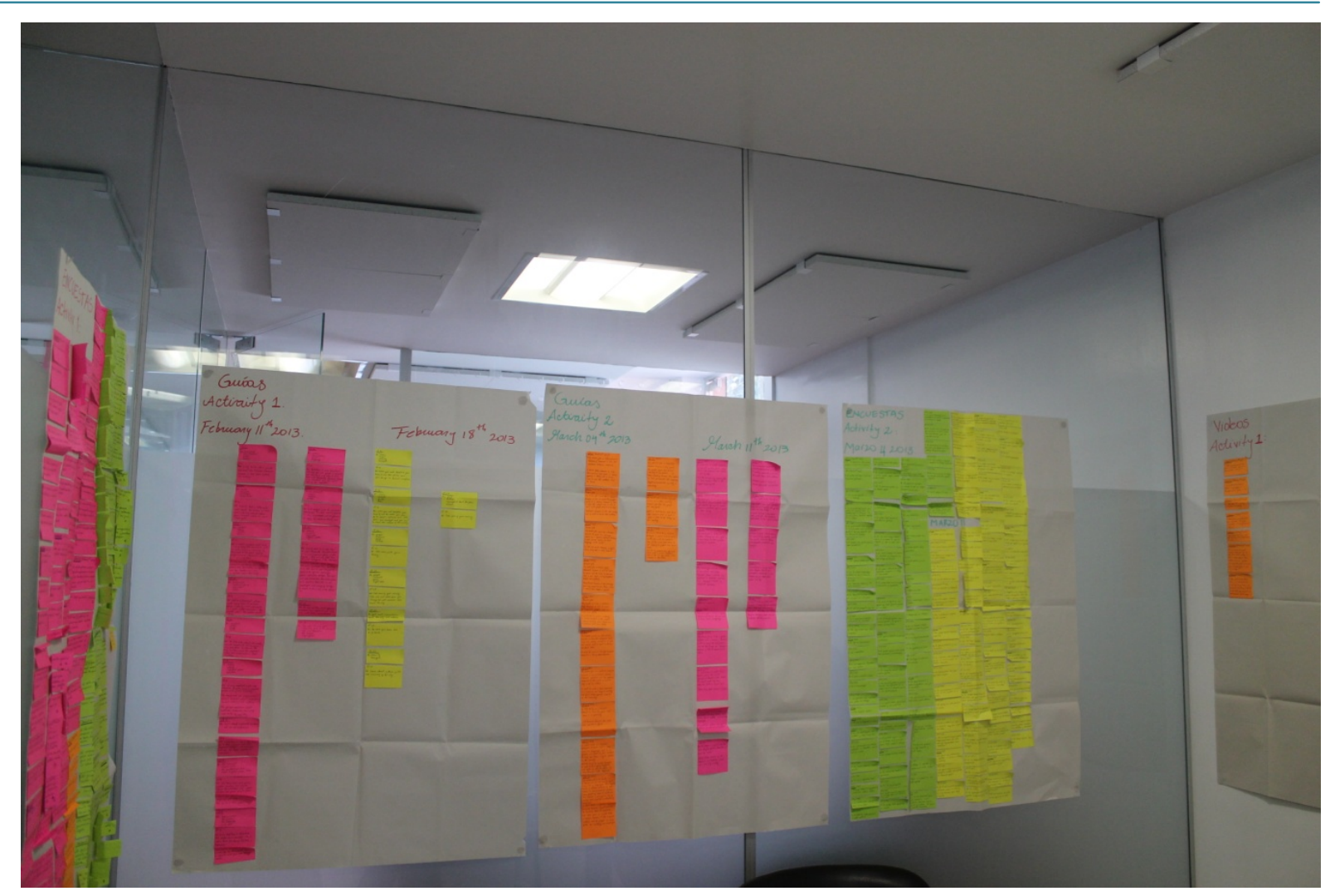

